\title{
World-wide variation in incidence of Acinetobacter associated ventilator associated pneumonia: a meta-regression
}

\author{
James C. Hurley ${ }^{1,2,3}$
}

\begin{abstract}
Background: Acinetobacter species such as Acinetobacter baumanii are of increasing concern in association with ventilator associated pneumonia (VAP). In the ICU, Acinetobacter infections are known to be subject to seasonal variation but the extent of geographic variation is unclear. The objective here is to define the extent and possible reasons for geographic variation for Acinetobacter associated VAP whether or not these isolates are reported as Acinetobacter baumanii.
\end{abstract}

Methods: A meta-regression model of VAP associated Acinetobacter incidence within the published literature was undertaken using random effects methods. This model incorporated group level factors such as proportion of trauma admissions, year of publication and reporting practices for Acinetobacter infection.

Results: The search identified 117 studies from seven worldwide regions over 29 years. There is significant variation in Acinetobacter species associated VAP incidence among seven world-wide regions. The highest incidence is amongst reports from the Middle East (mean; $95 \%$ confidence interval; 8.8; 6.2-12.7 per 1000 mechanical ventilation days) versus that from North American ICU's (1 $2 ; 0 \cdot 8-2 \cdot 1)$. There is a similar geographic related disparity in incidence among studies reporting specifically as Acinetobacter baumanii. The incidence in ICU's with a majority of admission being for trauma is $>2.5$ times that of other ICU's.

Conclusion: There is greater than fivefold variation in Acinetobacter associated VAP among reports from various geographic regions worldwide. This variation is not explainable by variations in rates of VAP overall, admissions for trauma, publication year or Acinetobacter reporting practices as group level variables.

Keywords: Intensive care unit, Geographic variation, Ventilator associated pneumonia, Acinetobacter

\section{Background}

Acinetobacter species are opportunistic gram negative bacteria which are of emerging concern in intensive care units worldwide [1-102]. Acinetobacter species accounted for $7.9 \%$ of bronchoscopically documented ventilator associated pneumonia in a series drawn predominantly from centres in Europe and The United States of America [103]. In contrast to other VAP pathogens, Acinetobacter species varies in incidence worldwide for reasons that remain to be fully defined.

\section{Correspondence: jamesh@bhs.org.au; hurleyjc@unimelb.edu.au}

${ }^{1}$ Department of Rural Health, Melbourne Medical School, University of

Melbourne, Ballarat 3353, Australia

${ }^{2}$ Internal Medicine Service, Ballarat Health Services, PO Box 577, Ballarat 3353,

Australia

Full list of author information is available at the end of the article
Acinetobacter baumannii has the greatest clinical importance amongst Acinetobacter species as it is typically associated with outbreaks in the hospital setting and it has major antimicrobial resistance issues. There is evidence for [104] and against [105] an increase in attributable mortality in association with Acinetobacter baumannii infections in the ICU.

Any survey of the worldwide epidemiology of Acinetobacter associated with VAP would be challenging for several reasons. First is that Acinetobacter infections in ICU are subject to seasonal influences [106-108]. For example, this is most apparent for Acinetobacter species blood stream infections versus other bacterial isolates such as Pseudomonas aeruginosa and appears to correspond with the higher outdoor air temperature [107]. For example, for each $10^{\circ} \mathrm{F}$ 
increase, Perencevich et al. observed a $17 \%$ increase in the monthly rates of infection from multiple body sites caused by $A$. baumanii at the University of Maryland Medical Center over a seven year period [108].

The second challenge is its potentially complex epidemiology. A. baumanii infection has the potential for the simultaneous occurrence of endogenous outbreak and nonoutbreak strains in an ICU together with, in tropical areas, natural disasters and military deployments, occasional community acquired infections [70, 109-111].

However, the greatest difficulty is in the vagaries and variations in the reporting practices of Acinetobacter species. The differentiation among Acinetobacter species may be challenging for a busy clinical microbiology laboratory as the microbiological identification on the basis of phenotypic characteristics is difficult $[101,102]$. As a consequence, the reporting and documentation to Acinetobacter species level may not be uniform across laboratories around the world and may be a high priority only in low incidence countries. While Acinetobacter baumannii is reported as the most frequently isolated species ( $>90$ percent of Acinetobacter species isolates) [101], this predominance may reflect the reporting practices of clinical microbiology laboratories.

Regional variation in the worldwide incidence has previously been described [102]. However, the quantification of this variation and moreover, the degree to which it may be explainable, are uncertain. The objective here is to define the extent of geographic variation within the published literature using meta-regression methods.

\section{Methods}

The literature search and analytic approach used here is as described previously [112]. In brief, an electronic search of PubMed, The Cochrane database and Google Scholar for systematic reviews containing potentially eligible studies was undertaken using the following search terms; "ventilator associated pneumonia", "mechanical ventilation", "intensive care unit", up to June 2016. This search was expanded to include reports that used the number of mechanical ventilation days as the denominator in addition to those reports that used the number of patients receiving prolonged mechanical ventilation as the denominator. These publications were reviewed for listing of VAP isolates including Acinetobacter. Because this analysis was based on a literature survey, institutional review board approval was not required.

The VAP associated Acinetobacter is the number of patients with VAP having an Acinetobacter species isolated from respiratory sampling. Where necessary, this number was derived as the number of patients with VAP multiplied by the proportion of VAP isolates that were Acinetobacter species. In addition, the following were also extracted where available; the number of ICU patients surveyed, the overall incidence of VAP per 1000 mechanically ventilated day (MVD), whether the mode of diagnosis of VAP required bronchoscopic sampling and whether the ICU was a trauma ICU (defined as more than $50 \%$ of admissions for trauma). Also, whether the mode of reporting of Acinetobacter infection was as Acinetobacter baumanii versus other modes such as Acinetobacter species was used as an indicator variable.

The assignment of countries to near neighbour groupings was solely determined in relation to geographic proximity without regard to political, economic or other considerations. For the purpose of generating a world map of Acinetobacter VAP incidence by country, summary rates by country were estimated were at least two study reports were available for that country.

A meta-regression model of VAP associated Acinetobacter was undertaken. The weight in this model is the inverse of the study variance. Because heterogeneity both within and between regions is to be expected, a random effects method was used for these estimates. The predictor variables in the regression model were the region from where the study originated, the mode of diagnosis of VAP, mode of reporting of Acinetobacter infection, trauma ICU and year of publication.

\section{Results}

The search identified 117 studies contained in 100 publications (Additional file 1) published over a period spanning 29 years [1-100]. The studies are detailed in the Additional file 1: Table S1-S6. The studies were classified by geographic region as detailed in Table 1 . There were 13 multinational ICU surveys from four publications which were classified separately (Additional file 1: Tables $\mathrm{S} 1$ ) as the incidence data in each of these ICU's were anonymized by originating country in these publications. The majority of the ICU's in these multinational studies were from outside of Europe and North America.

While none of the studies were undertaken in the context of an outbreak, six studies were undertaken in the context of an infection control intervention targeting overall ICU infection rates generally $[4,5,72,75,92]$ or VAP infections specifically [70]. The period of study ranged from 1 to 150 months. There were 11 studies $[1,44,54,60,69,74$, $83,86,91,92,97$ ] that could have been subject to seasonal variation in Acinetobacter incidence as the period of study in each was less than 12 months. These were excluded from the meta-regression model. There were 18 studies that reported for trauma ICU populations [2, 22, 32, 40, 43, 47, $50,53,55,66,67,70,82,-85,94,95]$.

The Acinetobacter associated with VAP was reported most commonly as Acinetobacter without speciation (i.e. Acinetobacter species; 53 studies). Acinetobacter VAP infections were less commonly reported as follows; Acinetobacter baumanii (47 studies); Acinetobacter calcoaceticus 
Table 1 Characteristics of studies ${ }^{\mathrm{a}}$

\begin{tabular}{|c|c|c|c|c|c|c|c|c|}
\hline & Multinational & Europe $^{b}$ & Mediterranean $^{\mathrm{b}}$ & Asia $^{\mathrm{b}}$ & Middle East ${ }^{\mathrm{b}}$ & $\begin{array}{l}\text { Central \& South } \\
\text { Americab }^{\text {b }}\end{array}$ & USA/Canadab & Ungrouped $^{b}$ \\
\hline Sources [ref] & $\begin{array}{l}\text { Additional file 1: } \\
\text { Table S1 } \\
\text { [S1-S4] }\end{array}$ & $\begin{array}{l}\text { Additional file 1: } \\
\text { Table S2 } \\
\text { [S5-S37] }\end{array}$ & $\begin{array}{l}\text { Additional file 1: } \\
\text { Table S3 } \\
\text { [S38-S57] }\end{array}$ & $\begin{array}{l}\text { Additional file 1: } \\
\text { Table S4 } \\
\text { [S58-S64] }\end{array}$ & $\begin{array}{l}\text { Additional file 1: } \\
\text { Table S4 } \\
\text { [S65-S73] }\end{array}$ & $\begin{array}{l}\text { Additional file 1: } \\
\text { Table S5 } \\
\text { [S74-S81] }\end{array}$ & $\begin{array}{l}\text { Additional file 1: } \\
\text { Table S5 } \\
\text { [S82-S96] }\end{array}$ & $\begin{array}{l}\text { Additional file } 1 \\
\text { Table S6 } \\
\text { [S97-S100] }\end{array}$ \\
\hline Number of groups & 13 & 35 & 20 & 7 & 11 & 9 & 18 & 4 \\
\hline MV for $>48 \mathrm{~h}$ for $<75 \%^{c}$ & 0 & 1 & 1 & 1 & 0 & 1 & 2 & 0 \\
\hline Trauma ICUs ${ }^{\mathrm{d}}$ & 1 & 2 & 6 & 0 & 4 & 0 & 6 & 0 \\
\hline Bronchoscopic sampling ${ }^{\mathrm{e}}$ & 3 & 18 & 13 & 1 & 1 & 1 & 7 & 1 \\
\hline Intervention period & 1 & 2 & 0 & 0 & 1 & 1 & 1 & 0 \\
\hline Study publication year (range) & 1993-2012 & 1988-2016 & $1987-2012$ & 2001-2016 & $2000-2013$ & $1995-2013$ & $1987-2014$ & $1987-2015$ \\
\hline $\begin{array}{l}\text { Numbers of patients per study } \\
\text { group; median (IQR) }\end{array}$ & $\begin{array}{l}2082 ; \\
1029-3413\end{array}$ & $\begin{array}{l}385 ; \\
145-764\end{array}$ & $\begin{array}{l}194 ; \\
101-318\end{array}$ & $\begin{array}{l}952 ; \\
301-16426\end{array}$ & $\begin{array}{l}260 ; \\
100-724\end{array}$ & $\begin{array}{l}270 ; \\
233-427\end{array}$ & $\begin{array}{l}340 ; \\
277-678\end{array}$ & $\begin{array}{l}174 ; \\
65-331\end{array}$ \\
\hline $\begin{array}{l}\text { Duration of MV (days); } \\
\text { median (IQR) }\end{array}$ & $6 ; 5-7$ & $11 ; 7.4-14$ & $8 ; 6.5-10.2$ & $7.5 ; 6-9$ & $8.9 ; 7.1-10$ & $9.6 ; 7.6-10$ & $5.5 ; 4-10.5$ & $9.2 ; 4-10.6$ \\
\hline \multicolumn{9}{|l|}{ VAP incidence; } \\
\hline $\begin{array}{l}\text { - per } 1000 \text { ventilator days; } \\
\text { o mean; }{ }^{\mathrm{f}} \\
\text { o } 95 \% \mathrm{Cl}\end{array}$ & $\begin{array}{l}30 \cdot 6 \\
20 \cdot 4-40 \cdot 7\end{array}$ & $\begin{array}{l}24 \cdot 3 \\
18 \cdot 1-30 \cdot 4\end{array}$ & $\begin{array}{l}29.8 \% \\
21 \cdot 4-38 \cdot 2\end{array}$ & $\begin{array}{l}29 \cdot 7 \\
15.9-43 \cdot 5\end{array}$ & $\begin{array}{l}34 \cdot 0 \\
22.9-44 \cdot 9\end{array}$ & $\begin{array}{l}31 \cdot 5 \\
19 \cdot 3-43 \cdot 6\end{array}$ & $\begin{array}{l}26 \cdot 7 \\
17 \cdot 9-35 \cdot 5\end{array}$ & $\begin{array}{l}33 \cdot 7 \\
15 \cdot 4-51 \cdot 9\end{array}$ \\
\hline \multicolumn{9}{|l|}{ Acinetobacter (all) VAP incidence ${ }^{g}$} \\
\hline $\begin{array}{l}\text { - per } 1000 \text { ventilator days; } \\
\text { o mean; } \\
\text { o } 95 \% \mathrm{Cl}\end{array}$ & $\begin{array}{l}4 \cdot 2 \\
2 \cdot 8-6 \cdot 2\end{array}$ & $\begin{array}{l}1 \cdot 3 \\
0.7-2 \cdot 5\end{array}$ & $\begin{array}{l}3 \cdot 5 ; \\
2.0-6 \cdot 1\end{array}$ & $\begin{array}{l}5.5 \\
2 \cdot 4-12 \cdot 8\end{array}$ & $\begin{array}{l}8.8 \\
6 \cdot 2-12 \cdot 7\end{array}$ & $\begin{array}{l}3 \cdot 3 \\
1 \cdot 8-6 \cdot 2\end{array}$ & $\begin{array}{l}1 \cdot 2 \\
0 \cdot 8-2 \cdot 1\end{array}$ & $\begin{array}{l}3 \cdot 1 \\
1 \cdot 9-5 \cdot 2\end{array}$ \\
\hline \multicolumn{9}{|l|}{$\begin{array}{l}\text { Acinetobacter baumanii VAP } \\
\text { incidence }{ }^{i}\end{array}$} \\
\hline $\begin{array}{l}\text { - per } 1000 \text { ventilator days; } \\
\text { o mean; }{ }^{j} \\
\text { o } 95 \% \mathrm{Cl}\end{array}$ & $\begin{array}{l}8 \cdot 2 ; \\
0 \cdot 7-3 \cdot 5\end{array}$ & $\begin{array}{l}0.51 ; \\
0.1-0 \cdot 9\end{array}$ & $\begin{array}{l}2 \cdot 8 \\
1 \cdot 4-5 \cdot 4\end{array}$ & $\begin{array}{l}6.6 \\
2 \cdot 1-20 \cdot 1\end{array}$ & $\begin{array}{l}18.0 \\
9 \cdot 8-33 \cdot 1\end{array}$ & $\begin{array}{l}4 \cdot 4 \\
2 \cdot 0-10 \cdot 0\end{array}$ & $\begin{array}{l}1 \cdot 2 \\
0 \cdot 6-2 \cdot 6\end{array}$ & \\
\hline
\end{tabular}

Abbreviations; ICU, Intensive care unit; MV; Mechanical ventilation; NA not applicable; VAP ventilator associated pneumonia; IQR, interquartile range
(and Europe includes France, Germany, United Kingdom, Switzerland, Sweden, Iceland, and Poland; Mediterranean includes Spain, Italy, Greece and Tunisia; Asia in Udes China, India, Pakstan and Bap includes Turkey, Iraq, Lebanon and Saudi Arabia; Central \& South America includes Argentina, Brazil, Chile, Colombia, Cuba and Guatemala; Northern America and South Africa

tudies for which less than $75 \%$ of patients were reported to receive more than $48 \mathrm{~h}$ of mechanical ventilation

${ }^{\mathrm{d}}$ Trauma ICU defined as an ICU with $>50 \%$ of patient admissions for trauma

MeaP Vic versus tracheal sampling toward the diagnosis of VAP

Mean VAP incidence (per 1000 Mix geographic regions; $p=0.74$

Acinetobacter (all) refers to Acinetobacter regardless of whether listing in the original study was as Acinetobacter species, Acinetobacter baumanii, or other speciation

${ }^{h}$ Mean Acinetobacter VAP incidence (per 1000 MV days) was significantly different between the six geographic regions; $p=0.003$

'Only from those studies that specified Acinetobacter baumanii

'Mean Acinetobacter VAP incidence from studies reporting as Acinetobacter baumanii (per $1000 \mathrm{MV}$ days) was significantly different between the six geographic regions; $\mathrm{p}=0.014$ 
(four studies); and Acinetobacter anitratus (two studies). There was no instance of any study reporting more than one Acinetobacter species type.

There was no significant difference in the overall VAP incidence across the region categories $(p=0.36$; Table 1 ; Additional file 1: Table S7). There was a significant variation in mean VAP associated Acinetobacter across the region categories (Fig. 6; $p=0.003$ ) with the Acinetobacter species associated VAP incidence being highest amongst reports from ICU's in the Middle East (mean; $95 \%$ confidence interval; $8.8 ; 6 \cdot 2-12 \cdot 7$ per 1000 mechanical ventilation days) versus reports from Northern Europe (1.3; 0.7-2.5) and North American ICU's $(1 \cdot 2$; $0 \cdot 8-2.1$ ) (Table 1).

A meta-regression of Log Acinetobacter VAP incidence per thousand MV days revealed no significant association with use of bronchoscopy for VAP diagnosis, or year of publication for Acinetobacter species associated VAP incidence (Table 2). For the purpose of the meta-regression and also for the caterpillar plots (Figs. 1, 2, 3, 4 and 5), the incidence in French studies was used as the benchmark incidence given that the largest number of studies originated from French ICU's. Both origin of study from the Middle East and also origin from a trauma ICU were each significant factors for a positive association for Acinetobacter species associated VAP incidence. Surprisingly, the mode of reporting of Acinetobacter VAP infection, whether as Acinetobacter baumanii versus other modes such as Acinetobacter species, was not a significant factor in these models. This is apparent in a summary figure for all studies (Fig. 6). The results of a meta-regression model limited to those studies that specifically reported as Acinetobacter baumanii gave similar findings (Table 2).

On the basis of the results of studies reporting incidence for single countries, a world map of Acinetobacter VAP infection incidence can be produced (Fig. 7).

\section{Discussion}

This is a survey of the incidence of Acinetobacter species associated VAP among published studies using metaanalysis to characterize the variation in incidence worldwide. It reinforces and further characterizes previous observations [101, 102]. It reveals a more than fivefold variation in incidence among seven broad world-wide and multinational regions that is not explainable by a limited number of group level factors.

There are major logistical challenges in undertaking any international survey and there are few prospective multinational comparisons of hospital acquired infections published. A worldwide prevalence survey

Table 2 Log Acinetobacter VAP incidence per thousand MV days; meta-regression models ${ }^{a}$

\begin{tabular}{|c|c|c|c|c|c|c|}
\hline \multirow[b]{2}{*}{ Factor } & \multicolumn{3}{|c|}{$\begin{array}{l}\text { Studies reporting as either Acinetobacter } \\
\text { species or Acinetobacter baumanii }\end{array}$} & \multicolumn{3}{|c|}{$\begin{array}{l}\text { Only studies reporting as Acinetobacter } \\
\text { baumanii }\end{array}$} \\
\hline & $\overline{\text { Coefficient }^{\mathrm{b}}}$ & $95 \% \mathrm{Cl}$ & $p$ & $\overline{\text { Coefficient }^{\mathrm{b}}}$ & $95 \% \mathrm{Cl}$ & $p$ \\
\hline $\begin{array}{l}\text { Northern European studies } \\
\text { (reference group) }\end{array}$ & $+0 \cdot 62$ & $-0 \cdot 37-+1 \cdot 6$ & & $+0 \cdot 71$ & $-2 \cdot 43-+1 \cdot 01$ & \\
\hline \multicolumn{7}{|l|}{ Geographic region } \\
\hline - Mediterranean & $+0 \cdot 65$ & $-0 \cdot 10-+1 \cdot 40$ & 0.09 & $+0 \cdot 33$ & $-0 \cdot 67-+1 \cdot 33$ & $0 \cdot 51$ \\
\hline - Asia & $+0 \cdot 71$ & $-0 \cdot 42-+1 \cdot 83$ & $0 \cdot 22$ & $+0 \cdot 05$ & $-1 \cdot 57-+1 \cdot 66$ & $0 \cdot 95$ \\
\hline - Middle East & $+1 \cdot 21$ & $+0 \cdot 28-+2 \cdot 13$ & $0 \cdot 01$ & $+1 \cdot 74$ & $+0 \cdot 20-+3 \cdot 28$ & $0 \cdot 03$ \\
\hline - Central \& South America & $+0 \cdot 53$ & $-0 \cdot 64-+1 \cdot 70$ & 0.37 & $+0 \cdot 56$ & $-1 \cdot 05-+2 \cdot 18$ & $0 \cdot 48$ \\
\hline - USA \& Canada & $-0 \cdot 90$ & $-1 \cdot 76--0 \cdot 04$ & $0 \cdot 04$ & $-1 \cdot 15$ & $-2 \cdot 45-+0 \cdot 15$ & $0 \cdot 08$ \\
\hline - Ungrouped & +0.28 & $-1 \cdot 56-+2.10$ & 0.77 & +0.31 & $-3 \cdot 36-+3.98$ & 0.87 \\
\hline • Multinational & +0.64 & $-0 \cdot 22-+1.49$ & 0.14 & +0.75 & $-0 \cdot 89-+2.4$ & 0.36 \\
\hline Trauma ${ }^{c}$ & +0.93 & $+0 \cdot 26-+1.59$ & 0.007 & $+0 \cdot 97$ & $+0 \cdot 001-+1.94$ & $0 \cdot 05$ \\
\hline Year of publication ${ }^{d}$ & $+0 \cdot 02$ & $-0 \cdot 04-+0 \cdot 04$ & 0.92 & $+0 \cdot 05$ & $-0 \cdot 02-+0 \cdot 12$ & $0 \cdot 14$ \\
\hline Mode of diagnosis ${ }^{e}$ & $-0 \cdot 26$ & $-0 \cdot 81-+0 \cdot 28$ & $0 \cdot 34$ & $+0 \cdot 10$ & $-0 \cdot 71-+0 \cdot 91$ & $0 \cdot 80$ \\
\hline Intervention period ${ }^{f}$ & -0.31 & $-1.4-+0.78$ & 0.57 & +0.22 & $-1.58-+2.02$ & 0.81 \\
\hline Acinetobacter baumanii ${ }^{9}$ & -0.06 & $-0 \cdot 61-+0 \cdot 50$ & $0 \cdot 84$ & & & \\
\hline
\end{tabular}

This table displays the results of a meta-regression analysis for log Acinetobacter VAP incidence per thousand MV days

${ }^{b}$ Interpretation. The reference group is the Northern European studies and this coefficient equals the difference in log from 0 (a log equal to 0 equates to a rate of

1. The other coefficients represent the difference in log for groups positive for that factor versus the reference group

'The co-efficient for trauma represents the increment in log for an ICU having a majority of admissions for trauma

${ }^{\mathrm{d}}$ The co-efficient for year of publication represents the linear increment in log for each year after 1980

eFor sampling using bronchoscopic versus tracheal sampling

fStudies undertaken during an infection control intervention

${ }^{g}$ Studies reporting Acinetobacter infections as Acinetobacter baumanii versus reporting as Acinetobacter species or otherwise 


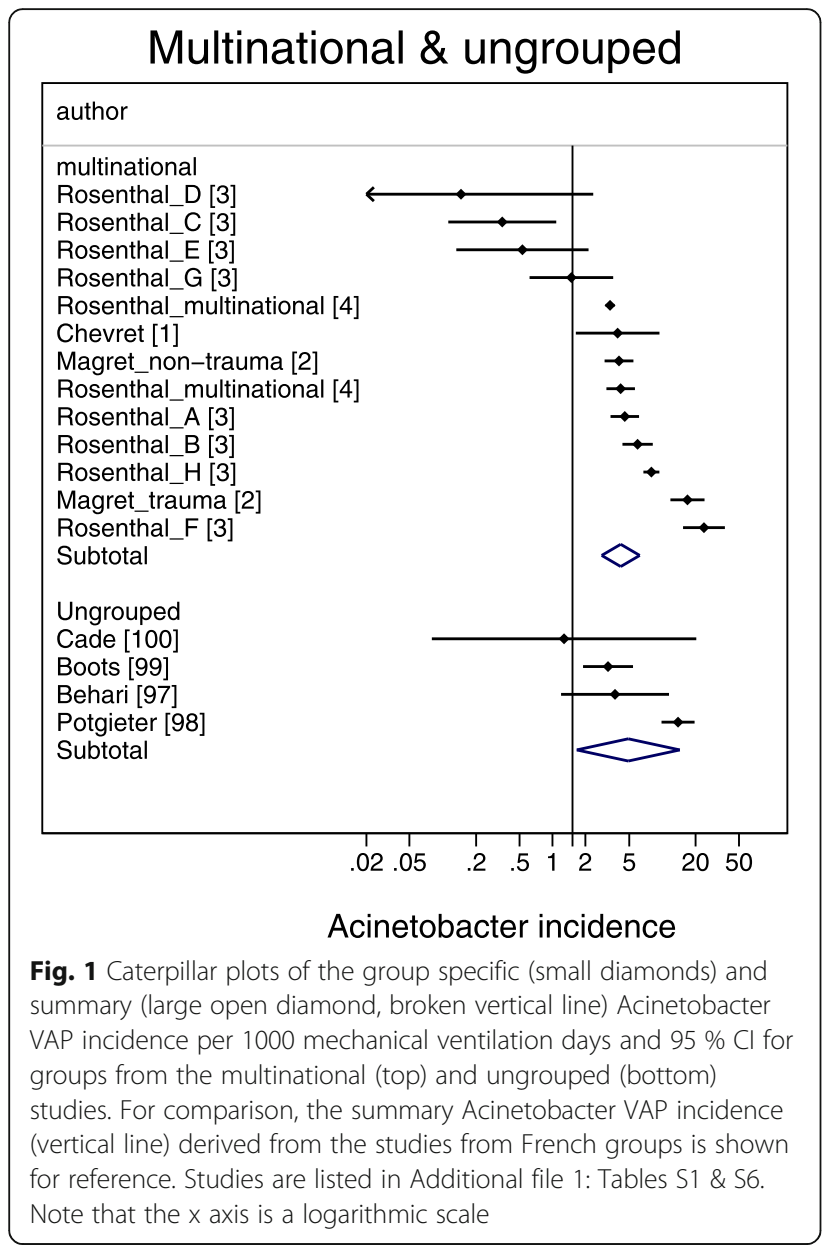

of Pseudomonas aeruginosa associated VAP across 11 countries during 2011-2012 revealed an insignificant variation in prevalence of both $P$. aeruginosa ventilator-associated pneumonia and also VAP overall across four regions; the United States, Europe, Latin America, and Asia Pacific [113]. By contrast, an anonymized survey of 55 ICUs of 46 hospitals in Argentina, Brazil, Colombia, India, Mexico, Morocco, Peru, and Turkey revealed an overall rate of VAP of 24.1 per 1000 MV days with Acinetobacter species accounting for between 3 and $46 \%$ of VAP isolates amongst the eight non-identified countries [3]. However, the extent to which any possible association with admission for trauma account for differences in VAP microbiology is difficult to establish in short term single center studies [114, 115].

Seasonal variation is another challenge to attempts at surveillance [106-108]. The seasonal variation amongst hospital acquired pneumonia and bloodstream Acinetobacter species infections was first documented in National Nosocomial Infections Surveillance System (NNIS) data and more recently within The Surveillance Network-USA database [106]. Acinetobacter species infections in these surveys

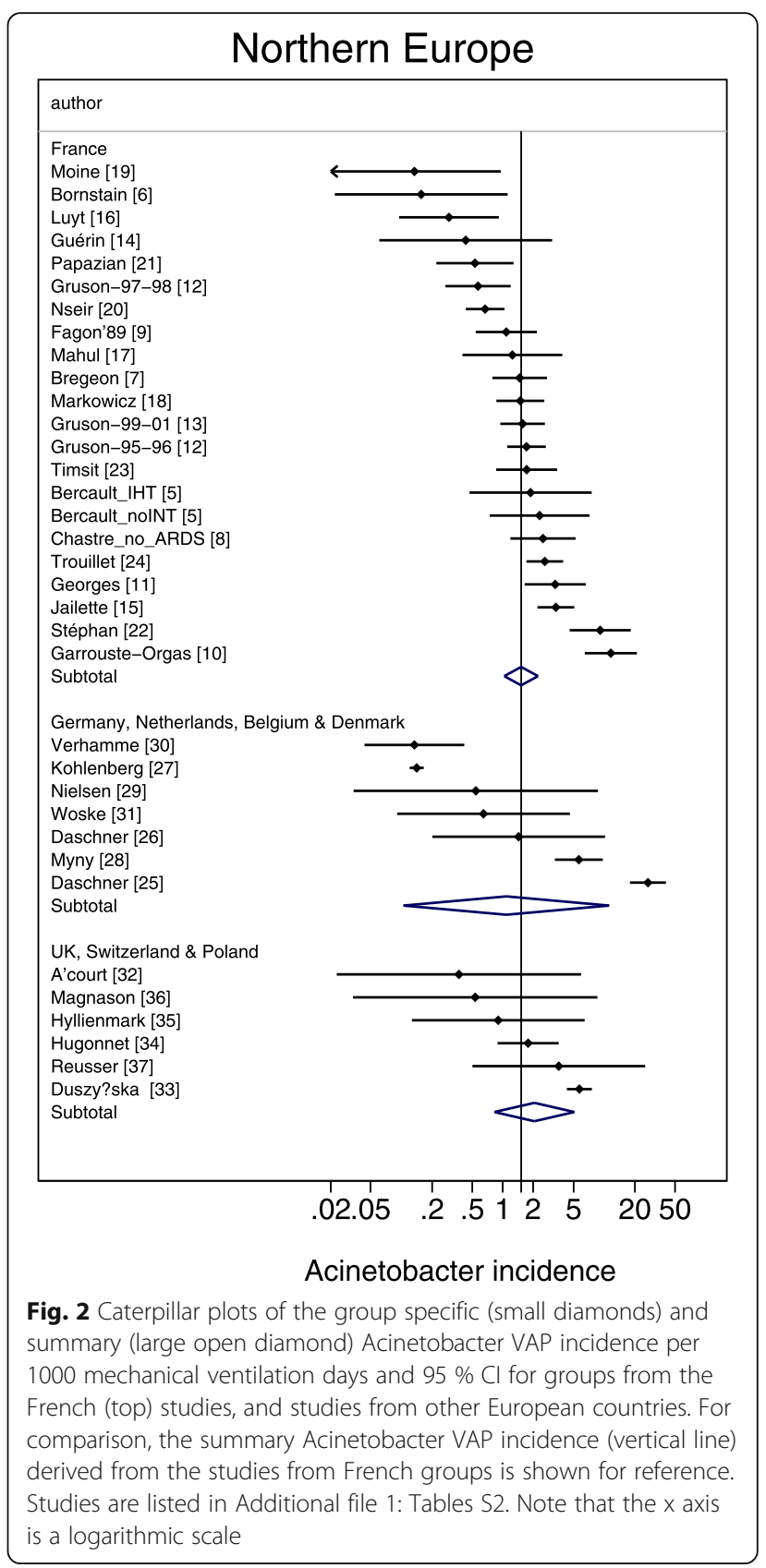

were $\sim 50 \%$ more common in summer than winter months. The variation seen here in this worldwide survey exceeds that explainable by seasonal variation. A possible mechanism to account for this seasonal and possibly geographic variation, and by contrast to species that do not exhibit the same variation, is that Acinetobacter and particularly $A$. baumanii have an exceptional ability to survive desiccation. It remains to speculate how this property of Acinetobacter could account for the variation found here. Of interest in this regard however, amongst a panel of Acinetobacter isolates, this ability to survive desiccation was notable for $A$. 




baumanii that had caused an outbreak of hospital acquired respiratory tract infections [116].

The advantage of a literature survey is that published data is readily available and the meta-regression methods for analysing these types of data are established. In contrast to multi-country incidence studies, which tend to be a snap shot over typically less than six months, most of the studies here extended over more than twelve months. Here a random effects methods is used. By using this method, the precision associated with each individual study estimate is incorporated in the derivation of both the overall summary estimate and in the derivation of the metaregression model. Moreover, in contrast to a fixed effects model, a random effect meta-regression model will generate more conservative summary estimates (i.e. wider $95 \%$ confidence limits) as the method incorporates both within and between study variability. In this way, comparisons to address questions of study

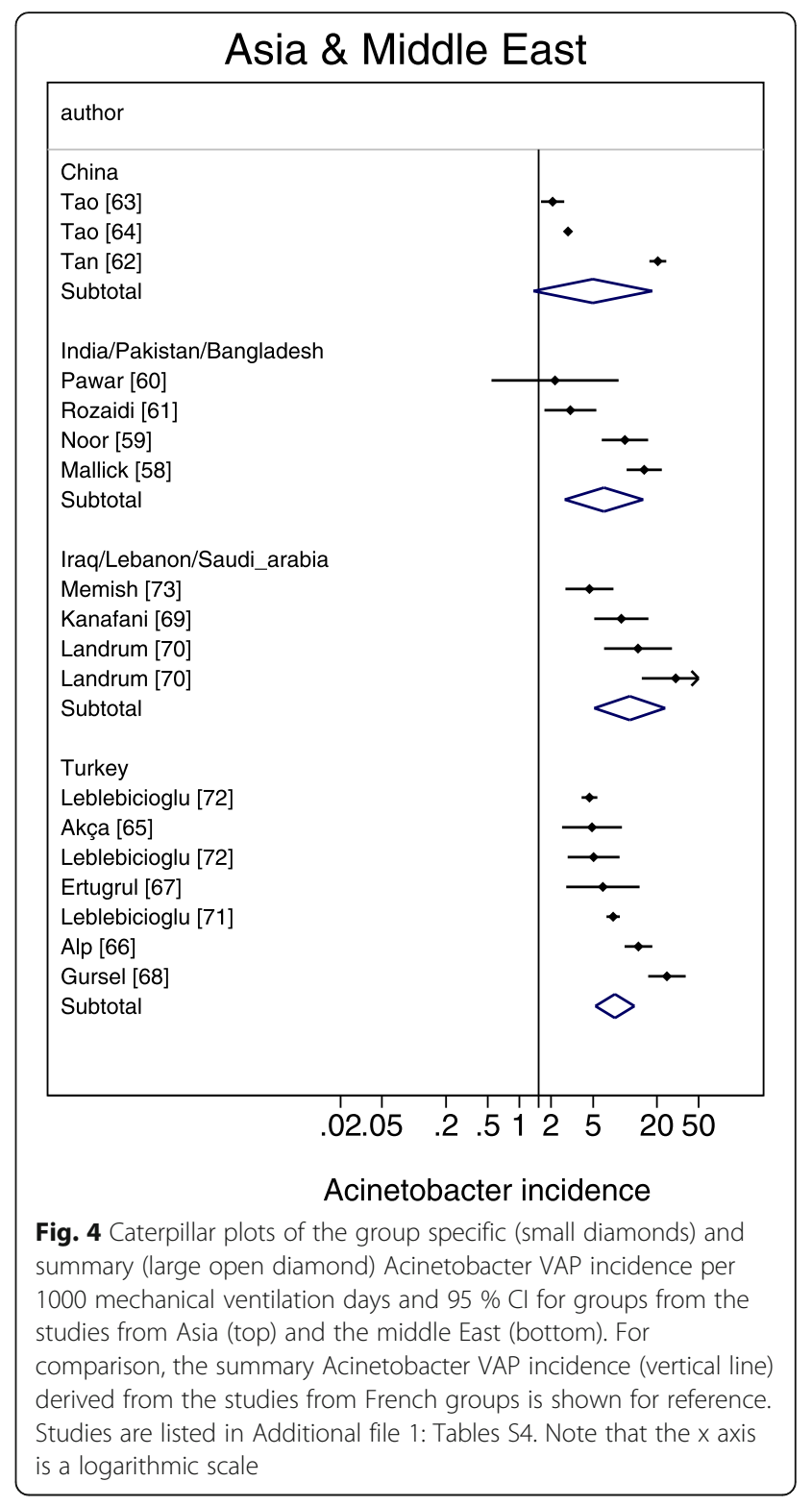

specific [115] and contextual [117] influences that would not be apparent within a single center study are enabled. As an example, the use of meta-regression can be used to benchmark control group pneumonia [112] and bacteremia [118] incidences in published prevention studies of VAP. The finding here of variability in incidence by region raises the possibility of contextual factors behind the variation.

There are several limitations to this literature based study. This is an analysis at the group level and is unable to take account of patient specific risk factors for Acinetobacter species associated VAP. For example, the usage of empiric antibiotic therapy in each study is an important unknown as use or nonuse may account for vulnerability to Acinetobacter 


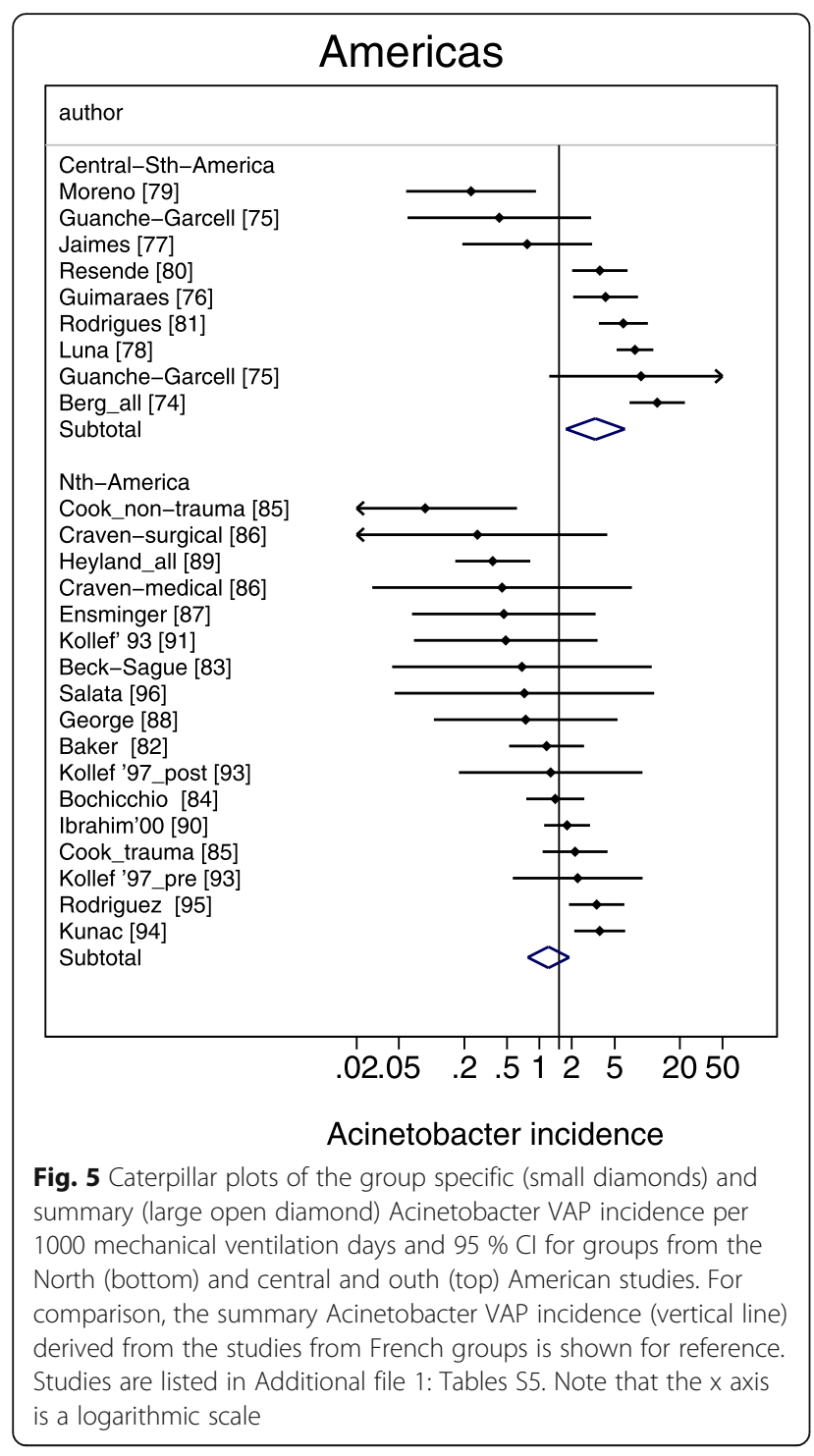

species associated VAP at the level of the individual patient $[119,120]$.

The grouping of countries into near neighbour groupings is somewhat arbitrary. Country and even regional groupings could be confounded by other variables such as infection control practices, prevalence of antibiotic use and standards of care for patients receiving mechanical ventilation that have not been able to be considered in the analysis here. Another limitation and difficult to exclude bias is the possible influence of publication bias.

The main limitation of a literature based survey is the lack of standardization across jurisdictions. It could be anticipated that there might be a range of clinical definitions used in the diagnosis of VAP at the level of the individual patient. That the mode of VAP diagnosis was not a significant factor in the regression model (Table 2) implies that this bias is likely to be minimal within a group level analysis as here. Likewise, the possibility of a linear time trend has been considered within the meta-regression model but this does not exclude the impact of trends more complex than linear.

An additional limitation is that for some reports, the VAP associated Acinetobacter, being the number of patients with VAP having an Acinetobacter species isolated from respiratory sampling, was not available. For these reports this number was derived as the number of patients with VAP multiplied by the proportion of VAP isolates that were Acinetobacter species. This is likely a reasonable approximation for a relatively rare outcome as found here. This approximation allows for VAP patients with multiple isolates.

A more difficult issue is that of laboratory documentation and reporting of Acinetobacter species type across jurisdictions. The striking observation among this survey was that all studies reported only one classification type of Acinetobacter. This was apparent in even the surveys with the most number of isolates [4, 27, 63]. The most common mode of reporting was as Acinetobacter species. Acinetobacter infections were less commonly reported as Acinetobacter baumanii from studies outside of Northern European and North American centers. It is possible that second line Acinetobacter species had been identified and listed within the category of 'other' gram negative infections. However, it remains a plausible explanation that the common practice in the literature reported here of the listing of a single Acinetobacter species generally reflects the mode of local reporting practices. In this regard and of pertinence to this survey of Acinetobacter baumanii, the reports of Acinetobacter species cannot be easily dismissed.

Of particular note, the rates of Acinetobacter VAP reported from studies reporting as Acinetobacter species versus studies reporting as Acinetobacter baumanii showed similar patterns of regional variation despite similar rates of overall VAP infection. Moreover, this regional variation in rates of Acinetobacter VAP were not explainable in a metaregression model by trauma ICU, year of publication and Acinetobacter reporting practice as group level variables whereas a comparable meta-regression model of VAP showed no major regional variation in overall VAP rates (Additional file 1: Table S7).

The methods in use in clinical microbiology laboratories likely varied not only geographically but also likely temporally over the three decades encompassed in this survey [121-125]. Because of the limitations of the traditional phenotypic testing methods $[121,122]$ for identification, a broad category of Acinetobacter calcoaceticus- $A$. baumanii complex was suggested at one point [121]. These phenotypic methods are being superseded by newer and more specific molecular methods [123-125]. Moreover, these and even newer 


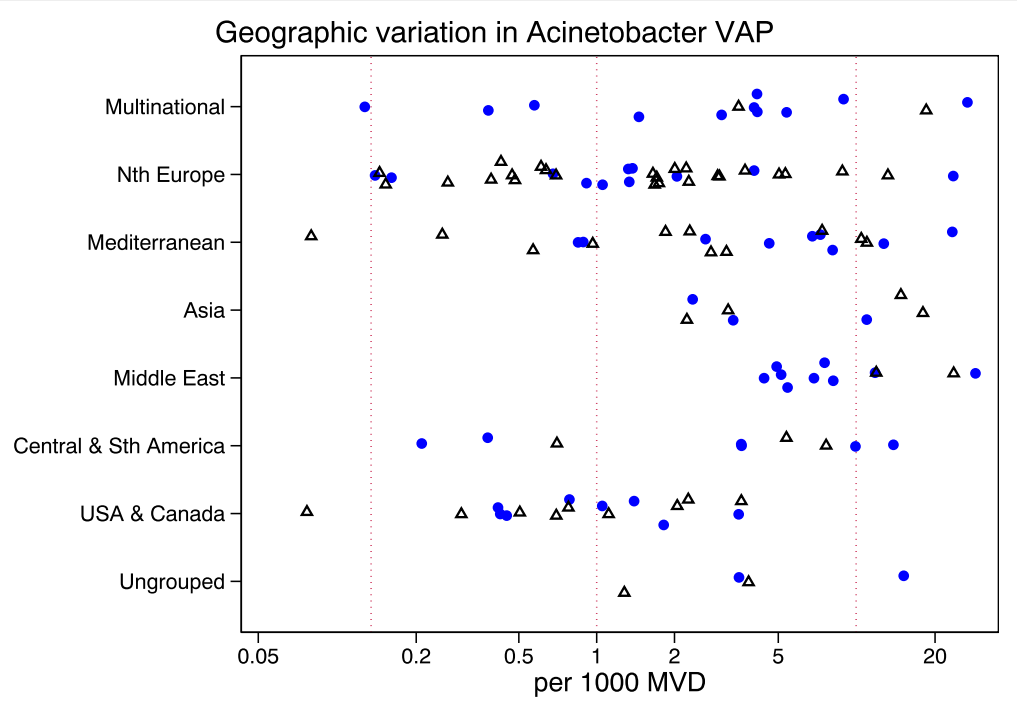

Fig. 6 A scatter plot of worldwide Acinetobacter VAP incidence (per 1000 MV days) among published studies in seven geographic regions with rates from studies reporting Acinetobacter infections as Acinetobacter baumanii (open symbols) versus reporting as Acinetobacter species or otherwise (closed symbols; Note logarithmic scale of incidence). The vertical lines are for reference at incidence rates of 0.1, 1 and 10 per $1000 \mathrm{mvd}$

methods such as MALDI-TOF for microbial detection and identification will likely further refine the identification and reporting of Acinetobacter species clinical isolates going forward.

The lower prevalence of Acinetobacter in cooler seasons [106-108] is consistent with the finding here that the prevalence is lower in reports from countries further away from the equator. The biological mechanism for this difference remains speculative. However, Acinetobacter species are gram negative bacteria which have important additional international public health issue for two further reasons. The transportation of patients around the world create the potential for infection control failures [111]. Moreover, Acinetobacter species are commonly multi-drug resistant although rates of resistance vary from region to region [126].



Fig. 7 A map of Acinetobacter VAP incidence per 1000 MV days for each country or world sub region for which at least two reports were available. Colour code; red >8; pink 6-8; yellow 4-6; green 2-4; blue < 2. Map modified from the following source; https://commons.wikimedia.org/ wiki/File\%3ABlankMap-World-v2.png By original uploader: Roke (Own work) [GFDL (http://www.gnu.org/copyleft/fdll.html) or CC-BY-SA-3.0 (http:// creativecommons.org/licenses/by-sa/3.0/)], via Wikimedia Commons from Wikimedia Commons 


\section{Conclusion}

There is a greater than fivefold variation in Acinetobacter associated VAP among published reports from various geographic regions worldwide. This variation is not explainable by variations in rates of VAP overall, admissions for trauma, publication year or Acinetobacter reporting practices as group level variables.

\section{Additional file}

Additional file 1: Tables of study data, a meta-regression of VAP incidence and listing of 100 references. (PDF $740 \mathrm{~kb}$ )

\section{Abbreviations}

ICU: Intensive Care Unit; MV: Mechanical ventilation; VAP: Ventilator associated pneumonia

\section{Funding}

This work was supported by the Australian Government Department of Health and Ageing through the Rural Clinical Training and Support (RCTS) program. The funding agency had no role in the preparation of the manuscript nor its approval for submission.

\section{Availability of data and materials}

The datasets supporting the conclusions of this article are included within the article and its additional file 1.

\section{Authors' contributions}

The author undertook the literature search, data analysis, manuscript preparation and approved its submission for publication and is the guarantor for this article.

\section{Competing interest}

The author declares that he has no competing interest.

\section{Ethics approval and consent to participate}

This article does not contain any studies with human participants performed by the author. Consent was not applicable.

\section{Author details}

'Department of Rural Health, Melbourne Medical School, University of Melbourne, Ballarat 3353, Australia. ${ }^{2}$ Internal Medicine Service, Ballarat Health Services, PO Box 577, Ballarat 3353, Australia. ${ }^{3}$ Infection Control Committees, St John of God Hospital and Ballarat Health Services, Ballarat, Victoria, Australia.

Received: 26 July 2016 Accepted: 12 October 2016

Published online: 18 October 2016

\section{References}

1. Chevret $\mathrm{S}$, Hemmer M, Carlet J, et al. Incidence and risk factors of pneumonia acquired in intensive care units. Results from a multicenter prospective study on 996 patients. European Cooperative Group on Nosocomial Pneumonia. Intensive Care Med. 1993:19:256-64.

2. Magret M, Amaya-Villar R, Garnacho J, Lisboa T, Diaz E, DeWaele J, Deja M, Manno E, Rello J, EU-VAP/CAP Study Group. Ventilator-associated pneumonia in trauma patients is associated with lower mortality: results from EU-VAP study. J Trauma Acute Care Surg. 2010;69(4):849-54.

3. Rosenthal VD, Maki DG, Salomao R, Moreno CA, Mehta Y, Higuera F, Cuellar LE, Arikan OA, Abouqal R, Leblebicioglu H. Device-associated nosocomial infections in 55 intensive care units of 8 developing countries. Ann Intern Med. 2006;145(8):582-91.

4. Rosenthal VD, Rodrigues C, Madani N, Mitrev Z, Ye G, Salomao R, Ulger F, Guanche-Garcell H, Kanj SS, Cuéllar LE, Higuera F. Effectiveness of a multidimensional approach for prevention of ventilator-associated pneumonia in adult intensive care units from 14 developing countries of four continents: Findings of the International Nosocomial Infection Control Consortium. Crit Care Med. 2012:40(12):3121-8.

5. Bercault $\mathrm{N}$, Wolf $\mathrm{M}$, Runge I, et al. Intrahospital transport of critically ill ventilated patients: a risk factor for ventilator-associated pneumonia-a matched cohort study. Crit Care Med. 2005;33:2471-8.

6. Bornstain C, Azoulay E, De Lassence A, Cohen Y, Costa MA, Mourvillier B, Descorps-Declere A, Garrouste-Orgeas M, Thuong M, Schlemmer B, Timsit JF. Sedation, sucralfate, and antibiotic use are potential means for protection against early-onset ventilator-associated pneumonia. Clin Infect Dis. 2004;38(10):1401-8.

7. Bregeon F, Papazian L, Visconti A, Gregoire R, Thirion X, Gouin F. Relationship of microbiologic diagnostic criteria to morbidity and mortality in patients with ventilator-associated pneumonia. JAMA. 1997;277:655-62.

8. Chastre J, Trouillet JL, Vuagnat A, et al. Nosocomial pneumonia in patients with acute respiratory distress syndrome. Am J Respir Crit Care Med. 1998:157:1165-72

9. Fagon JY, Chastre J, Domart Y, Trouillet JL, Pierre J, Darne C, Gibert C. Nosocomial pneumonia in patients receiving continuous mechanical ventilation. Prospective analysis of 52 episodes with use of a protected specimen brush and quantitative culture techniques. Am Rev Respir Dis. 1989;139:877-84.

10. Garrouste-Orgeas M, Chevret S, Arlet G, et al. Oropharyngeal or gastric colonization and nosocomial pneumonia in adult intensive care unit patients. A prospective study based on genomic DNA analysis. Am J Respir Crit Care Med. 1997;156:1647-56.

11. Georges H, Leroy O, Guery B, Alfandari S, Beaucaire G. Predisposing factors for nosocomial pneumonia in patients receiving mechanical ventilation and requiring tracheotomy. Chest. 2000;118:767-74.

12. Gruson D, Hilbert G, Vargas F, Valentino R, Bebear C, Allery A, Bebear C, Gbikpi-benissan GE, Cardinaud JP. Rotation and restricted use of antibiotics in a medical intensive care unit: impact on the incidence of ventilatorassociated pneumonia caused by antibiotic-resistant gram-negative bacteria. Am J Respir Crit Care Med. 2000;162(3):837-43.

13. Gruson D, Hilbert G, Vargas F, et al. Strategy of antibiotic rotation: long-term effect on incidence and susceptibilities of Gram-negative bacilli responsible for ventilator-associated pneumonia. Crit Care Med. 2003;31:1908-14.

14. Guerin C, Girard R, Chemorin C, De Varax R, Fournier G. Facial mask noninvasive mechanical ventilation reduces the incidence of nosocomial pneumonia. Intensive Care Med. 1997;23(10):1024-32.

15. Jaillette $\mathrm{E}$, Nseir $\mathrm{S}$. Relationship between inhaled $\beta 2$-agonists and ventilatorassociated pneumonia: A cohort study. Crit Care Med. 2011:39(4):725-30

16. Luyt CE, Guerin V, Combes A, et al. Procalcitonin kinetics as a prognostic marker of ventilator-associated pneumonia. Am J Respir Crit Care Med. 2005;171:48-53.

17. Mahul P, Auboyer C, Jospe R, Ros A, Guerin C, el Khouri Z, Galliez M, Dumont A, Gaudin O. Prevention of nosocomial pneumonia in intubated patients respective role of mechanical subglottic secretions drainage and stress ulcer prophylaxis. Intensive Care Med. 1992;18:20-5.

18. Markowicz P, Wolff M, Djedaini K, Cohen Y, Chastre J, Delclaux C. Multicenter prospective study of ventilator-associated pneumonia during acute respiratory distress syndrome. Incidence, prognosis, and risk factors. ARDS Study Group. Am J Respir Crit Care Med. 2000;161:1942-8.

19. Moine $P$, Timsit JF, De Lassence $A$, et al. Mortality associated with late-onset pneumonia in the intensive care unit: results of a multi-center cohort study. Intensive Care Med. 2002;28:154-63.

20. Nseir S, Di Pompeo C, Soubrier S, Cavestri B, Jozefowicz E, Saulnier F, Durocher A. Impact of ventilator-associated pneumonia on outcome in patients with COPD. Chest. 2005;128(3):1650-6.

21. Papazian $L$, Bregeon $F$, Thirion $X$, et al. Effect of ventilator-associated pneumonia on mortality and morbidity. Am J Respir Crit Care Med. 1996;154:91-7.

22. Stéphan F, Mabrouk N, Decailliot F, Delclaux C, Legrand P. Ventilatorassociated pneumonia leading to acute lung injury after trauma: importance of Haemophilus influenzae. Anesthesiol. 2006;104:235-41.

23. Timsit JF, Chevret S, Valcke J, et al. Mortality of nosocomial pneumonia in ventilated patients: influence of diagnostic tools. Am J Respir Crit Care Med. 1996:154:116-23.

24. Trouillet JL, Chastre J, Vuagnat A, Joly-Guillou ML, Combaux D, Dombret MC, Gibert C. Ventilator-associated pneumonia caused by potentially drugresistant bacteria. Am J Respir Crit Care Med. 1998;157(2):531-9. 
25. Daschner F, Kappstein I, Schuster F, et al. Influence of disposable ('Conchapak') and reusable humidifying systems on the incidence of ventilation pneumonia. J Hosp Infect. 1988;11:161-8.

26. Daschner F, Kappstein I, Engels I, Reuschenbach K, Pfisterer J, Krieg N, Vogel W. Stress Ulcer Prophylaxis and Ventilation Pneumonia Prevention by Antibacterial Cytoprotective Agents? Infect Control. 1988;9(02):59-65.

27. Kohlenberg A, Schwab F, Behnke M, Geffers C, Gastmeier P. Pneumonia associated with invasive and noninvasive ventilation: an analysis of the German nosocomial infection surveillance system database. Intensive Care Med. 2010;36(6):971-8.

28. Myny D, Depuydt P, Colardyn F, Blot S. Ventilator-associated pneumonia in a tertiary care ICU analysis of risk factors for acquisition and mortality. Acta Clin Belg. 2005;60:114-21.

29. Nielsen SL, Roder B, Magnussen P, et al. Nosocomial pneumonia in an intensive care unit in a Danish university hospital: incidence, mortality and etiology. Scand J Infect Dis. 1992;24:65-70

30. Verhamme KM, De Coster W, De Roo L, De Beenhouwer H, Nollet G, Verbeke J, Demeyer I, Jordens P. Pathogens in early-onset and late-onset intensive care unit-acquired pneumonia. Infect Control Hosp Epidemiol. 2007;28(04):389-97.

31. Woske HJ, Röding T, Schulz I, Lode H. Ventilator-associated pneumonia in a surgical intensive care unit Epidemiology, etiology and comparison of three bronchoscopic methods for microbiological specimen sampling. Crit Care. 2001;5:167-73.

32. $A^{\prime}$ Court CH, Garrard CS, Crook D, et al. Microbiological lung surveillance in mechanically ventilated patients, using non-directed bronchial lavage and quantitative culture. Q J Med. 1993;86:635-48.

33. Duszyńska W, Rosenthal VD, Dragan B, Węgrzyn P, Mazur A, Wojtyra P, Tomala A, Kübler A. Ventilator-associated pneumonia monitoring according to the INICC project at one centre. Anaesthesiol Intensive Ther. 2015:47(1):34-9.

34. Hugonnet S, Uçkay I, Pittet D. Staffing level: a determinant of late-onset ventilator-associated pneumonia. Crit Care. 2007;11(4):R80.

35. Hyllienmark P, Gardlund B, Persson JO, Ekdahl K. Nosocomial pneumonia in the ICU: a prospective cohort study. Scand J Infect Dis. 2007;39:676-82.

36. Magnason S, Kristinsson KG, Stefansson T, Erlendsdottir H, Jonsdottir K, Kristjansson M, Gudmundsson S. Risk factors and outcome in ICU-acquired infections. Acta Anaesthesiol Scand. 2008;52:1238-45.

37. Reusser P, Zimmerli W, Scheidegger D, Marbet GA, Buser M, Gyr K. Role of gastric colonization in nosocomial infections and endotoxemia: a prospective study in neurosurgical patients on mechanical ventilation. J Infect Dis. 1989;160:414-21.

38. Alvarez-Lerma F. ICU-acquired Pneumonia Study Group. Modification of empiric antibiotic treatment in patients with pneumonia acquired in the intensive care unit. Intensive Care Med. 1996;22(5):387-94.

39. Baraibar J, Correa H, Mariscal D, Gallego M, Valles J, Rello J. Risk factors for infection by Acinetobacter baumannii in intubated patients with nosocomial pneumonia. Chest. 1997:112(4):1050-4

40. Cavalcanti M, Ferrer M, Ferrer R, et al. Risk and prognostic factors of ventilator associated pneumonia in trauma patients. Crit Care Med. 2006:34:1067-72.

41. Cardenosa Cendrero JA, Sole-Violan J, Bordes Benitez A, et al. Role of different routes of tracheal colonization in the development of pneumonia in patients receiving mechanical ventilation. Chest. 1999;116:462-70.

42. de Latorre FJ, Pont T, Ferrer A, et al. Pattern of tracheal colonization during echanical ventilation. Am J Respir Crit Care Med. 1995;152:1028-33.

43. Ewig S, Torres A, El-Ebiary M, et al. Bacterial colonization patterns in mechanically ventilated patients with traumatic and medical head injury. Incidence, risk factors, and association with ventilator-associated pneumonia. Am J Respir Crit Care Med. 1999;159:188-98.

44. Jimenez $\mathrm{P}$, Torres A, Rodriguez-Roisin R, et al. Incidence and etiology of pneumonia acquired during mechanical ventilation. Crit Care Med. 1989:17:882-5.

45. Rello J, Quintana E, Ausina V, et al. Incidence, etiology, and outcome of nosocomial pneumonia in mechanically ventilated patients. Chest. 1991; 100:439-44

46. Rello J, Lorente C, Diaz E, et al. Incidence, etiology, and outcome of nosocomial pneumonia in ICU patients requiring percutaneous tracheotomy for mechanical ventilation. Chest. 2003;124:2239-43.

47. Rincón-Ferrari MD, Flores-Cordero JM, Leal-Noval SR, Murillo-Cabezas F, Cayuelas A, Muñoz-Sánchez MA, Sánchez-Olmedo Jl. Impact of ventilatorassociated pneumonia in patients with severe head injury. J Trauma Acute Care Surg. 2004;57(6):1234-40.
48. Ruiz-Santana S, Garcia Jimenez A, Esteban A, et al. ICU pneumonias: a multiinstitutional study. Crit Care Med. 1987;15:930-2.

49. Tamayo E, Álvarez FJ, Martínez-Rafael B, Bustamante J, Bermejo-Martin JF, Fierro I, Eiros JM, Castrodeza J, Heredia M, Gómez-Herreras JI, Valladolid Sepsis Study Group. Ventilator-associated pneumonia is an important risk factor for mortality after major cardiac surgery. J Crit Care. 2012;27(1):18-25.

50. Tejada Artigas A, Bello Dronda S, Chacon Valles E, et al. Risk factors for nosocomial pneumonia in critically ill trauma patients. Crit Care Med. 2001;29:304-9.

51. Torres A, Aznar R, Gatell JM, et al. Incidence, risk, and prognosis factors of nosocomial pneumonia in mechanically ventilated patients. Am Rev Respir Dis. 1990;142:523-8.

52. Violan JS, Sanchez-Ramirez C, Mujica AP, Cendrero JC, Fernandez JA, de Castro FR. Impact of nosocomial pneumonia on the outcome of mechanically-ventilated patients. Crit Care (Lond). 1998;2:19-23.

53. Antonelli M, Moro ML, Capelli O, et al. Risk factors for early onset pneumonia in trauma patients. Chest. 1994;105:224-8.

54. Apostolopoulou E, Bakakos P, Katostaras T, et al. Incidence and risk factors for ventilator-associated pneumonia in 4 multidisciplinary intensive care units in Athens, Greece. Respir Care. 2003;48:681-8.

55. Kallel H, Chelly H, Bahloul M, Ksibi H, Dammak H, Chaari A, Hamida CB, Rekik N, Bouaziz M. The effect of ventilator-associated pneumonia on the prognosis of head trauma patients. J Trauma Acute Care Surg. 2005;59(3):705-10.

56. Piazza O, lasiello A, Papalanni C, De Robertis E, Servillo G, Rossano F, Tufano $R$. Incidence of antimicrobial-resistant ventilator associated pneumonia: an eighteen-month survey. Panminerva Med. 2005;47(4):265-7.

57. Sofianou DC, Constandinidis TC, Yannacou M, et al. Analysis of risk factors for ventilator-associated pneumonia in a multidisciplinary intensive care unit. Eur J Clin Microbiol Infect Dis. 2000;19:460-3.

58. Mallick UK, Faruq MO, Ahsan AA, Fatema K, Ahmed F, Asaduzzaman M, Islam M, Sultana A. Spectrum of Early Onset and Late Onset Ventilator Associated Pneumonia (VAP) in a Tertiary Care Hospital of Bangladesh: A Prospective Cohort Study. Bangladesh Crit Care J. 2015;3(1):9-13.

59. Noor A, Hussain SF. Risk factors associated with development of ventilator associated pneumonia. J Coll Physicians Surg Pak. 2005;15:92-5.

60. Pawar M, Mehta Y, Khurana P, Chaudhary A, Kulkarni V, Trehan N. Ventilatorassociated pneumonia: incidence, risk factors, outcome, and microbiology. J Cardiothorac Vasc Anesth. 2003;17(1):22-8.

61. Rozaidi SW, Sukro J, Dan A. The incidence of nosocomial infection in the Intensive Care Unit, Hospital Universiti Kebangsaan Malaysia: ICU-acquired nosocomial infection surveillance program 1998-1999. Med J Malaysia. 2001:56(2):207-22.

62. Tan X, Zhu S, Yan D, Chen W, Chen R, Zou J, Yan J, Zhang X, Farmakiotis D, Mylonakis E. Candida spp. airway colonization: A potential risk factor for Acinetobacter baumannii ventilator-associated pneumonia. Med Mycol 2016;54(6):557-66

63. Tao L, Hu B, Rosenthal VD, Gao X, He L. Device-associated infection rates in 398 intensive care units in Shanghai, China: International Nosocomial Infection Control Consortium (INICC) findings. Int J Infect Dis. 2011;15(11):e774-80.

64. Tao L, Hu B, Rosenthal VD, Zhang Y, Gao X, He L. Impact of a multidimensional approach on ventilator-associated pneumonia rates in a hospital of Shanghai: findings of the International Nosocomial Infection Control Consortium. J Crit Care. 2012;27(5):440-6.

65. Akça O, Koltka K, Uzel S, et al. Risk factors for early-onset, ventilatorassociated pneumonia in critical care patients: selected multiresistant versus non-resistant bacteria. Anesthesiol. 2000;93:638-45.

66. Alp E, Güven M, Yıldız O, Aygen B, Voss A, Doganay M. Incidence, risk factors and mortality of nosocomial pneumonia in intensive care units: a prospective study. Ann Clin Microbiol Antimicrob. 2004;3(1):1.

67. Ertugrul BM, Yildirim A, Ay P, Oncu S, Cagatay A, Cakar N, Ertekin C, Ozsut H, Eraksoy $\mathrm{H}$, Calangu S. Ventilator-associated pneumonia in surgical emergency intensive care unit. Saudi Med J. 2006;27(1):52-7.

68. Gursel G, Aydogdu M, Nadir Ozis T, Tasyurek S. Comparison of the value of initial and serial endotracheal aspirate surveillance cultures in predicting the causative pathogen of ventilator-associated pneumonia. Scand J Infect Dis. 2010;42:341-6.

69. Kanafani ZA, Kara L, Hayek S, et al. Ventilator-associated pneumonia at a tertiary-care center in a developing country: incidence, microbiology, and 
susceptibility patterns of isolated microorganisms. Infect Control Hosp Epidemiol. 2003;24:864-9.

70. Landrum ML, Murray CK. Ventilator associated pneumonia in a military deployed setting: the impact of an aggressive infection control program. Trauma Acute Care Surg. 2008;64(2):S123-8.

71. Leblebicioglu H, Rosenthal VD, Arıkan ÖA, Özgültekin A, Yalcin AN, Koksal I, Usluer G, Sardan YC, Ulusoy S. Device-associated hospitalacquired infection rates in Turkish intensive care units. Findings of the International Nosocomial Infection Control Consortium (INICC). J Hosp Infect. 2007;65(3):251-7.

72. Leblebicioglu H, Yalcin AN, Rosenthal VD, Koksal I, Sirmatel F, Unal S, Turgut H, Ozdemir D, Ersoz G, Uzun C, Ulusoy S. Effectiveness of a multidimensional approach for prevention of ventilator-associated pneumonia in 11 adult intensive care units from 10 cities of Turkey: findings of the International Nosocomial Infection Control Consortium (INICC). Infect. 2013;41(2):447-56.

73. Memish ZA, Cunningham G, Oni GA, et al. The incidence and risk factors of ventilator-associated pneumonia in a Riyadh hospital. Infect Control Hosp Epidemiol. 2000;21:271-3.

74. Berg DE, Hershow RC, Ramirez CA, Weinstein RA. Control of nosocomial infections in an intensive care unit in Guatemala City. Clin Infect Dis. 1995;21:588-93.

75. Guanche-Garcell H, Morales-Perez C, Rosenthal VD. Effectiveness of a multidimensional approach for the prevention of ventilator-associated pneumonia in an adult intensive care unit in Cuba: findings of the International Nosocomial Infection Control Consortium (INICC).J Infect Public Health. 2013;6:98-107.

76. Guimaraes MM, Rocco JR. Prevalence of ventilator-associated pneumonia in a university hospital and prognosis for the patients affected. J Bras Pneumol. 2006:32:339-46.

77. Jaimes F, De La Rosa G, Gómez E, Múnera P, Ramírez J, Castrillón S. Incidence and risk factors for ventilator-associated pneumonia in a developing country Where is the difference? Respir Med. 2007;101:762-7.

78. Luna CM, Blanzaco D, Niederman MS, et al. Resolution of ventilatorassociated pneumonia: prospective evaluation of the clinical pulmonary infection score as an early clinical predictor of outcome. Crit Care Med. 2003;31:676-82.

79. Moreno CA, Rosenthal VD, Olarte N, Gomez WW, Sussmann O, Agudelo JG, Rojas C, Osorio L, Linares C, Valderrama A, Mercado PG. Device-associated infection rate and mortality in intensive care units of 9 Colombian hospitals: findings of the International Nosocomial Infection Control Consortium. Infect Control. 2006;27(04):349-56.

80. Resende MM, Monteiro SG, Callegari B, Figueiredo PM, Monteiro CR, Monteiro-Neto V. Epidemiology and outcomes of ventilator-associated pneumonia in northern Brazil: an analytical descriptive prospective cohort study. BMC Infect Dis. 2013;13(1):119.

81. Rodrigues PM, Neto C, Santos LR, Knibel MF. Ventilator-associated pneumonia: epidemiology and impact on the clinical evolution of ICU patients. J Bras Pneumol. 2009;35(11):1084-91.

82. Baker AM, Meredith JW, Haponik EF. Pneumonia in intubated trauma patients. Microbiology and outcomes. Am J Respir Crit Care Med. 1996; 153:343-9.

83. Beck-Sague CM, Sinkowitz RL, Chinn RY, et al. Risk factors for ventilatorassociated pneumonia in surgical intensive-care-unit patients. Infect Control Hosp Epidemiol. 1996;17:374-6.

84. Bochicchio GV, Joshi M, Bochicchio K, et al. A time-dependent analysis of intensive care unit pneumonia in trauma patients. Trauma. 2004;56:296-301.

85. Cook A, Norwood S, Berne J. Ventilator-associated pneumonia is more common and of less consequence in trauma patients compared with other critically ill patients. J Trauma Acute Care Surg. 2010;69(5):1083-91.

86. Craven DE, Kunches LM, Lichtenberg DA, et al. Nosocomial infection and fatality in medical and surgical intensive care unit patients. Arch Intern Med. 1988;148:1161-8.

87. Ensminger SA, Wright RS, Baddour LM, Afess B. Suspected ventilatorassociated pneumonia in cardiac patients admitted to the coronary care unit. Mayo Clin Proc. 2006:81:32-5.

88. George DL, Falk PS, Wunderink RG, Leeper Jr KV, Meduri GU, Steere EL, Glen MC. Epidemiology of ventilator-acquired pneumonia based on protected bronchoscopic sampling. Am J Respir Crit Care Med. 1998;158:1839-47.
89. Heyland DK, Cook DJ, Griffith L, Keenan SP, Brun-Buisson C. The attributable morbidity and mortality of ventilator-associated pneumonia in the critically ill patient. The Canadian Critical Trials Group. Am J Respir Crit Care Med. 1999:159:1249-56.

90. Ibrahim EH, Ward S, Sherman G, Kollef MH. A comparative analysis of patients with early-onset vs late-onset nosocomial pneumonia in the ICU setting. Chest. 2000;117:1434-42.

91. Kollef MH. Ventilator-associated pneumonia. A multivariate analysis. JAMA. 1993:270:1965-70

92. Kollef MH, Silver P, Murphy DM, et al. The effect of late-onset ventilator-associated pneumonia in determining patient mortality. Chest. 1995;108:1655-62.

93. Kollef MH, Vlasnik J, Sharpless L, Pasque C, Murphy D, Fraser V. Scheduled change of antibiotic classes A strategy to decrease the incidence of ventilator-associated pneumonia. Am J Respir Crit Care Med. 1997;156:1040-8.

94. Kunac A, Sifri ZC, Mohr AM, Horng H, Lavery RF, Livingston DH. Bacteremia and Ventilator-Associated Pneumonia: A Marker for Contemporaneous Extra-Pulmonic Infection. Surg Infect. 2014;15:77-83.

95. Rodriguez $\mathrm{JL}$, Gibbons KJ, Bitzer LG, et al. Pneumonia: incidence, risk factors, and outcome in injured patients. J Trauma. 1991;31:907-12.

96. Salata RA, Lederman MM, Shlaes DM, Jacobs MR, Eckstein E, Tweardy D, Toossi Z, Chmielewski R, Marino J, King CH. Diagnosis of nosocomial pneumonia in intubated, intensive care unit patients. Am Rev Respir Dis. 1987;135:426-32.

97. Behari AA, Kalafatis N. Incidence and outcome of ventilator-associated pneumonia in Inkosi Albert Luthuli and King Edward VIII Hospital surgical intensive care units. Southern African J Crit Care (Online). 2015;31(1):16-8.

98. Potgieter PD, Linton DM, Oliver S, Forder AA. Nosocomial infections in a respiratory intensive care unit. Crit Care Med. 1987;15:495-8.

99. Boots RJ, Phillips GE, George N, Faoagali UL. Surveillance culture utility and safety using low-volume blind bronchoalveolar lavage in the diagnosis of ventilator-associated pneumonia. Respirology. 2008;13:87-96.

100. Cade JF, McOwat E, Siganporia R, Keighley C, Presneill J, Sinickas V. Uncertain relevance of gastric colonization in the seriously ill. Intensive Care Med. 1992;18:210-7.

101. Munoz-Price LS, Weinstein RA. Acinetobacter infection. New Eng J Med. 2008;358(12):1271-81.

102. Falagas $M E$, Karveli EA, Siempos II, Vardakas KZ. Acinetobacter infections: a growing threat for critically ill patients. Epidemiol Infect. 2008;136(08):1009-19.

103. Chastre J, Fagon JY. Ventilator-associated pneumonia. Am J Respir Crit Care Med. 2002:165(7):867-903.

104. Falagas ME, Bliziotis IA, Siempos II. Attributable mortality of Acinetobacter baumannii infections in critically ill patients: a systematic review of matched cohort and case-control studies. Crit Care. 2006;10(2):1.

105. Garnacho J, Sole-Violan J, Sa-Borges M, Diaz E, Rello J. Clinical impact of pneumonia caused by Acinetobacter baumannii in intubated patients: a matched cohort study. Crit Care Med. 2003;31(10):2478-82.

106. McDonald LC, Banerjee SN, Jarvis WR. National Nosocomial Infections Surveillance System. Seasonal variation of Acinetobacter infections: 19871996. Clin Infect Dis. 1999;29(5):1133-7.

107. Eber MR, Shardell M, Schweizer ML, Laxminarayan R, Perencevich EN. Seasonal and temperature-associated increases in gram-negative bacterial bloodstream infections among hospitalized patients. PLoS ONE. 2011;6(9):e25298.

108. Perencevich EN, McGregor JC, Shardell M, Furuno JP, Harris AD, Morris JG, Fisman DN, Johnson JA. Summer peaks in the incidences of gram-negative bacterial infection among hospitalized patients. Infect Control Hosp Epidemiol. 2008;29(12):1124-31.

109. Fournier $P E$, Richet $H$, Weinstein RA. The epidemiology and control of Acinetobacter baumannii in health care facilities. Clin Infect Dis. 2006:42(5):692-9.

110. Anstey NM, Currie BJ, Withnall KM. Community-acquired Acinetobacter pneumonia in the Northern Territory of Australia. Clin Infect Dis. 1992;14:83-91.

111. Uckay I, Sax H, Harbarth S, Bernard L, Pittet D. Multi-resistant infections in repatriated patients after natural disasters: lessons learned from the 2004 tsunami for hospital infection control. J Hosp Infect. 2008;68(1):1-8.

112. Hurley JC. Ventilator Associated Pneumonia prevention methods using topical antibiotics: herd protection or herd peril? Chest. 2014;146(4):890-8 
113. Kollef MH, Chastre J, Fagon JY, François B, Niederman MS, Rello J, et al. Global prospective epidemiologic and surveillance study of ventilatorassociated pneumonia due to Pseudomonas aeruginosa. Crit Care Med. 2014;42(10):2178-87.

114. Agbaht K, Lisboa T, Pobo A, et al. Management of ventilator-associated pneumonia in a multidisciplinary intensive care unit: does trauma make a difference? Intensive Care Med. 2007;33(8):1387-95.

115. Hurley JC. Profound effect of study design factors on ventilator-associated pneumonia incidence of prevention studies: benchmarking the literature experience. J Antimicrob Chemother. 2008;61:1154-61.

116. Wendt C, Dietze B, Dietz E, Rüden H. Survival of Acinetobacter baumannii on dry surfaces. J Clin Microbiol. 1997;35(6):1394-7.

117. Hurley JC. Inapparent outbreaks of ventilator-associated pneumonia: an ecologic analysis of prevention and cohort studies. Infect Control Hosp Epidemiol. 2005:26:374-90.

118. Hurley JC. Topical antibiotics as a major contextual hazard toward bacteremia within selective digestive decontamination studies: a metaanalysis. BMC Infect Dis. 2014;14:714.

119. Medina J, Formento C, Pontet J, Curbelo A, Bazet C, Gerez J, Larrañaga E. Prospective study of risk factors for ventilator-associated pneumonia caused by Acinetobacter species. J Crit Care. 2007;22(1):8-26.

120. Garnacho-Montero J, Ortiz-Leyba C, Fernández-Hinojosa E, Aldabó-Pallás T, Cayuela A, Marquez-Vácaro JA, Garcia-Curiel A, Jiménez-Jiménez FJ. Acinetobacter baumannii ventilator-associated pneumonia: epidemiological and clinical findings. Intensive Care Med. 2005;31(5):649-55.

121. Turton JF, Shah J, Ozongwu C, Pike R. Incidence of Acinetobacter species other than A. baumannii among clinical isolates of Acinetobacter: evidence for emerging species. J Clin Microbiol. 2010;48(4):1445-9.

122. Gerner-Smidt PE, Tjernberg I, Ursing J. Reliability of phenotypic tests for identification of Acinetobacter species. J Clin Microbiol. 1991;29(2):277-82.

123. Bosshard PP, Zbinden R, Abels S, Böddinghaus B, Altwegg M, Böttger EC. $16 S$ rRNA gene sequencing versus the API 20 NE system and the VITEK 2 ID-GNB card for identification of nonfermenting Gram-negative bacteria in the clinical laboratory. J Clin Microbiol. 2006;44(4):1359-66.

124. Bernards AT, Van der Toorn J, Van Boven CP, Dijkshoorn L. Evaluation of the ability of a commercial system to identifyAcinetobacter genomic species. Eur J Clin Microbiol Infect Dis. 1996;15(4):303-8.

125. Lee MJ, Jang SJ, Li XM, Park G, Kook JK, Kim MJ, Chang YH, Shin JH, Kim SH, Kim DM, Kang SH. Comparison of rpoB gene sequencing, 16S rRNA gene sequencing, gyrB multiplex PCR, and the VITEK2 system for identification of Acinetobacter clinical isolates. Diag Microbiol Infect Dis. 2014;78(1):29-34.

126. Lob SH, Hoban DJ, Sahm DF, Badal RE. Regional differences and trends in antimicrobial susceptibility of Acinetobacter baumannii. Int J Antimicrob Agent. 2016;47(4):317-23.

\section{Submit your next manuscript to BioMed Central and we will help you at every step:}

- We accept pre-submission inquiries

- Our selector tool helps you to find the most relevant journal

- We provide round the clock customer support

- Convenient online submission

- Thorough peer review

- Inclusion in PubMed and all major indexing services

- Maximum visibility for your research

Submit your manuscript at www.biomedcentral.com/submit

) Biomed Central 